when others did not seem to understand how hard it was just to cope with everyday life and two children under 2 .

Then came a whole series of complications from shingles to bronchopneumonia and gastroenteritis. More help was needed with the children, even though Ruth so dearly wanted to be able to do without it. Somehow, I fitted in part I of the membership of the Royal College of Psychiatrists rather than postpone the examination yet again.

At the beginning of March Ruth felt more than usually unwell and we attended outpatients for the umpteenth time. We waited anxiously, as so often before, for the results of the bone marrow aspiration. When they came I heard, once more by telephone, the news that we both most feared.

Friends who, like us, were doctors were stunned. Others, while deeply saddened, often seemed less aware of the tragic change in prognosis compared with Ruth's two previous illnesses where the prognosis had been poor enough to start with. What we did not expect was the rapid decline that occurred later the same month. I am so glad that we talked about death while it still seemed months or more away. All too quickly we could no longer talk and suddenly I discovered what anticipatory grief really meant. I appreciated those precious hours alone with Ruth before she died as much as I regretted the lack of opportunity to talk and share with her any more. When she did die there was all too brief a time to grieve and then a mountain of practical things to do.

\section{God's share in our grief}

In a very real sense I feel as though we both had leukaemia. If "illness" really is a concept to be distinguished from "disease" then perhaps this has some objective as well as subjective validity. Ruth's death has brought release of our family from that illness by removal of her disease. In its place are the pangs of bereavement and the struggle to start a new life as a one parent family. Families matter and are ignored by surgeons or physicians, as well as psychiatrists, at great cost. I am so glad that the doctors and nurses who cared for Ruth cared also for Andrew, Beth, and me.

Did God care? Was our faith in Him unjustified? Five days after Ruth died it was Good Friday. We remembered a God who loves us so much that $\mathrm{He}$ shares our suffering. I believe that $\mathrm{He}$ shared with us in Ruth's illness and that He shares our tears in bereavement. His death was not a defeat and so, I believe, neither was Ruth's, for she shares in His victory.

\title{
Do gooders: down and outs in Leeds crypt
}

\author{
ROBIN CARMICHAEL
}

Down and outs do not immediately excite our sympathy; rather we think of them as antisocial alcoholics, who have finally arrived on skid row. Some are like that. Television coverage of the soup kitchens and shelters set up around Christmas time gives us a different view. It usually contrives to show us one or two relatively articulate men, who are portrayed as "characters" choosing to be fiercely independent of any attempt by social services or do gooders to impose some kind of respectability or conformity on them. A few are indeed like that, but most men are not like either of these caricatures.

\section{Regular patients}

Some 55 years ago under the leadership of the church's visionary minister, Don Robins, the crypt of St George's church in Leeds was cleared of its crumbling coffins and their rather gruesome contents. The stench was overcome, the vaults reconstructed, the place renovated and decorated, and its doors opened as a shelter. Twelve years ago, long after the nurses had set the pace and pricked their consciences, doctors began a regular surgery in the crypt on three evenings a week. For six years I have been one of a group of doctors trying to meet some of the medical needs of this strange group of men, who are literally the outcasts of society.

As always happens with voluntary work, participation is a revelation. You realise that although the men have much in common with each other they are very different, and the stereotype group identity begins to separate out into Joe, the low IQ man with

Bramhope, Leeds LS16 9AG

ROBIN CARMICHAEL, MB, MRCGP, general practitioner

Correspondence to: 2 Parklands Gate, Breary Lane, Bramhope, Leeds LS16 9AG. epilepsy and no family; Jimmy, the kindly alcoholic, who has no more aggression in him than the average goldfish; Pat, the one with schizophrenia whose inability to cope with anybody pushes him back on the streets despite endless attempts at providing hostel accommodation. The Salvation Army, Church Army, and social services still seek to help where there are no easy solutions. There is Andy, the illiterate and difficult psychopath, whose explosive temper keeps him from leading any kind of conventional life. There are occasional frightening men, who by clever or bullying tactics hope to obtain drugs of one sort or another. There are inadequate personalities of all sorts, with sad histories behind their dishevelled, unkempt beards; pathetic men, tired and confused; simple men, but so complicated that no-one can help them. There are a few rogues, a few seemingly wicked, a few scroungers and malingerers, but almost all through little fault of their own have ended up homeless and adrift.

\section{My contribution}

I am no saint. After a long or difficult surgery at the end of a working day I have often almost decided to quit as a medical helper. There have been occasions in the clinic when I have been impatient or defensive or unyielding when a little flexibility might have avoided an unpleasant confrontation. I find that I seldom know how to begin solving these men's fundamental problems, nor do I even know how society should provide and care for them. Certainly I know fewer answers than when I started. I no longer believe that more than the odd middle class notion or two has any relevance to the needs of this group at the very bottom of the social pecking order. Most of the men should, I suppose, be in some kind of institution, but some do not have the resources of character to cope with living in any kind of institution. In my more reflective moments as I consider these shortcomings I am aware that I am singularly ill equipped to offer my services, yet I do go back.

I go back because many of the men's problems are those which 
any general practitioner is dealing with daily. We are on the look out for tuberculosis; men may need sick notes; they often have chest infections, dirty wounds, gastrointestinal disorders, epilepsy, angina, or skin diseases. Many request a hypnotic to help them to sleep on the floor or a bench (there are no beds in the crypt); they may ask for reassurance that various aches and pains are musculoskeletal and nothing more serious; they sometimes warrant referral to a specialist; they sometimes accept treatment for schizophrenia. We listen to tales-real, fanciful or hallucinatory; we help men withdrawing from alcohol.

I go back because many of the men are genuinely likeable. I go back because the warden, a clergyman with psychiatric nursing experience and a degree in psychology, works his heart out for the men and he wants doctors to help while he patiently strives to do everything possible through his network of allies in the social services, Christian agencies, voluntary workers, probation and prison services. I go back because, selfishly, there is emotional satisfaction-even prestige-in being a helper to people so unfortunate. I go back because occasionally I have been able to offer profound comfort to an ill or suffering individual.

I go back because without a hint of false humility I can say that there is not much difference between them and me. We are human, but I have the privileges. I possess a good education, a fulfilling job, a happy family, a faith that inspires me. All these have been given to me. If they had not, then perhaps I, too, would be of no fixed abode-a misfit in a world that I could not understand where officials and charities offer crumbs of comfort, where drink takes some of the hardness from the floors of derelict buildings, and the company of fellow vagrants offers some kind of comradeship and sense of community.

Most long stay psychiatric units have closed their doors. Now it is proposed that reception centres run by the Department of Health and Social Security are to close theirs. We will need a few more do gooders.

\title{
Residential holiday for schoolchildren
}

\author{
N J SHAW
}

The excitement and fulfilment of being in charge of a residential holiday for children are not easy to convey in writing. I arrive with the advance party a day before, usually at a residential school that is not being used in the summer holidays. Twenty four hours is not a long time to meet the owner; clean the whole place; sort out bedrooms and beds; brief the domestic staff; discuss menus, eating times, special diets, and birthday cakes with the caterer; and prepare for the planned activities of the week ahead.

\section{Arrival}

Early afternoon on the day of arrival of the main party an expectant lull falls over the holiday centre and then all of a sudden they arrive- 60 travel weary 9 to 13 year olds accompanied by eight young adults (the monitors). Suitcases and rucksacks are everywhere, shouts of "Where's the sweet shop?" "Me and my friend want to sleep in the same room," "I bet the food's rotten," and "Can I sleep in a bunk bed?" prevail, interspersed with encouraging remarks of "Wait here for the moment until you're told what to do," and "We'll be unpacking soon and then it'll be teatime." Chaos attempts to reign but by luck or by judgment the children are dispersed in groups with their respective monitors and find the dormitory that will be their home for the next week. Then the walls begin to echo with the sound of suitcases emptying and clothes lists being checked by monitors. An evening of games follows a noisy teatime and when the last child is tucked up in bed asleep, worn out with all the excitement, the adults converge for a staff meeting. Questions concerning left over sandwiches, empty suitcases, and safe keeping of children's pocket money are dealt with. A skeleton programme is outlined for the week and we discuss the handful of children who are showing the early signs of homesickness. They may be quiet and withdrawn, feel sick, or have a tummy pain and

Royal Hospital for Sick Children, Edinburgh EH9 1LF N J SHAW, MB, CHB, paediatric registrar headache. After half an hour's informal chat we too retire for the night.

The following week is filled with games, drama, handicrafts, swimming, story telling, singing, a concert, and walks to places of interest, and each evening we have our staff meeting to reflect on the preceding day and to relax. Time flies by and it is not long before I am waving goodbye to 68 adults and children who disappear over the horizon looking like one big happy family, which I have had the privilege to be part of.

Colony Children's Holidays is a non-profit making charity, which aims to provide educational holidays for children between 8 and 15 years from all social backgrounds and all parts of the country. It has no religious or political affiliation. The presiding council consists of members from most education authorities whose social work departments recommend children for the holidays. Some are aided by the Colony Holidays sponsorship fund. The organisation has affiliated organisations in Liverpool, Leeds, and Northern Ireland, where Children's Community Holidays take over 1000 children a year on holidays throughout the province. The workers attend a week long residential training course to become a monitor and two further training courses to be in overall charge of a holiday.

\section{Fostering a feeling of community}

Children from different backgrounds have different needs and expectations and the holidays are aimed at integrating these in a residential setting. Much emphasis is laid on the community aspect of living under the same roof and a group structure is generally employed. We hope this encourages working together in an atmosphere of mutual tolerance and understanding and provides an enjoyable and rewarding experience. The adults also gain from this experience. They are called by their first names and learn to treat each child with respect as an individual. In return they are respected as friends, helpers, and in their position in loco parentis. I am sure that this all sounds idealistic but it generally works-you only have to be part of a long walk in the countryside or a peaceful story telling or singing session by the fire, or experience the atmosphere of a concert produced by the children, to understand what I mean.

One of the most exciting aspects for me is the participation of children with special needs on these holidays. Children with hearing 